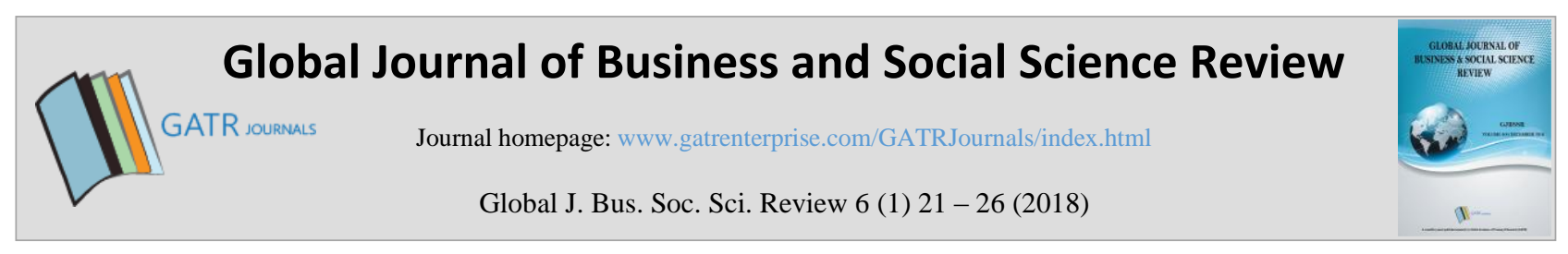

\title{
Effectiveness of Differentiated Instruction Training to Enhance Teachers' Sense of Efficacy in Inclusive Schools
}

\author{
Mira Aliza Rachmawati ${ }^{1}$, Nur Widiasmara ${ }^{2}$, Thobagus Muh Nu'man ${ }^{3}$ \\ ${ }^{1,2,3}$ Universitas Islam Indonesia, Jl. Kaliurang km 14,5 Besi Sleman, 55584, Yogyakarta, Indonesia
}

\begin{abstract}
Objective - This study aims to determine the effect of differentiated instruction training on teachers' efficacy at inclusion schools in Jogjakarta.

Methodology/Technique - The subjects in this study consist of 5 school teachers working in elementary inclusion schools in Baciro Yogyakarta. The data were collected using the Teacher Sense of Efficacy Scale (TSES), which is adapted from Woolfolk and Hoy (1993). This is an experimental study, using one group pre-test and post-test. The data is analyzed using the Wilcoxon test.

Findings - The findings show that there is a significant difference in the efficacy of inclusion school teachers before and after the training is given, where the value $\mathrm{Z}=-2.023$ and $\mathrm{p}=0.0438(\mathrm{p}<0.05)$.

Novelty - This study demonstrates that differentiated instruction teacher training can improve the sense of efficacy in school teachers working in inclusion elementary schools in Baciro Jogjakarta.
\end{abstract}

Type of Paper: Empirical.

Keywords: Differentiated Instruction Training; Effectiveness; Teacher Efficacy; Inclusion Schools; Indonesia.

JEL Classification: I21, I29.

\section{Introduction}

Inclusion schools combine children with and without special needs in educational settings. The underlying principle of inclusive education is that all children should have an equal opportunity to study together (NCSE in Mahony, 2016). In Indonesia, the number of elementary schools in operation has increased in recent times. However, the increasing number of inclusion schools in Indonesia is not accompanied by the readiness of schools to provide competent teachers in line with demand. Therefore, inclusion schools often employ teachers from special needs schools to assist the teachers with special needs children. However, the number of teachers from special needs schools remains inadequate. In addition, special needs teachers have an exceptionally heavy workload, which may reduce their effectiveness when assisting inclusive schools.

\footnotetext{
${ }^{*}$ Paper Info: Revised: December, 21, 2017

Accepted: February, 16, 2018

* Corresponding author:

E-mail: miraaliza@uii.ac.id

Affiliation: Universitas Islam Indonesia, Jl. Kaliurang km 14,5 Besi Sleman, 55584, Yogyakarta, Indonesia
} 
Facing such conditions, inclusion schools are now recruiting class teachers and volunteers who are interested in, and concerned about, inclusive education. However, these classroom teachers and volunteers still do not have a special needs education background. As a result, class teachers or volunteers have not been able to use the learning processes tailored to children with special needs. Ideally, special needs teachers should possess the required competency, be able to create warmth for students and to accept various differences, and create a learning process tailored to children with special needs. Special needs teachers should also be able to optimize the abilities of both students with and without special needs. In inclusive education, teachers should be able to cater to different students' academic, social and cultural needs (Rose, cited in in Forlin, 2013).

In fact, not all special needs teachers are able to adequately handle with children with special needs. Most special needs teachers have low self-efficacy to create a conducive learning environment for their students, and are less confident in their ability to educate students with special needs. This low self-efficacy ultimately leads teachers to use the same teaching strategies for all students, regardless of their ability. As a result, children with special needs are often not able to follow the lessons delivered by the teacher. Ideally, inclusive schools should recognize and respond to the different needs of their students, accommodate the different styles and speeds of learning, and ensure quality education for all students through the development of appropriate curriculums, school organization, appropriate selection of teaching strategies, appropriate use of resources, and involvement with the community.

Teachers' efficacy was identified as an important variable in education more than 25 years ago (Cakiroglu, cited in Shaukat and Iqbal, 2012). According to research conducted by Avramidis and Norwich (Specht et al., 2015), the teachers' attitudes efficacy with respect to inclusion are closely related to the prevalence of inclusive schools. Further, a study by Florian and Black-Hawkins; Jordan, Glenn, and McGhie Richmond (Specht et al., 2015) identified that teachers need self-efficacy in teaching all students and should have the knowledge and skills to be able to teach in inclusive schools. The self-efficacy of teachers is therefore a key element of competence for educators in inclusive schools (Specht et al., 2015). In addition, the results of Sharma, Loreman, and Forlin (Chao, Forlin, and Ho, 2016) indicate that self-efficacy is the key to success in creating inclusive classroom environments. Armor et al. and Bandura (Moran and Hoy, 2001) also explain that teacher efficacy is an assessment of a teacher's ability to encourage students to succeed in learning, regardless of their ability or motivations.

Therefore, to improve the efficacy of teachers in inclusive schools, it is important that teachers have an understanding of appropriate teaching strategies for children with special needs. Teachers should be able to create a learning environment that is able to respond to the different learning needs of different students. A learning environment that adequately uses instructional practices enables students to learn and develop according to their abilities (Corno, 2008).

Differentiated instruction is considered a promising response to the varying abilities of students in the classroom. Differentiated instruction refers to a teaching strategy that provides different ways of learning for students tailored to variations in their readiness, interests, and learning profiles (Tomlinson, 2001; Tomlinson et al., 2003). Furthermore, Tomlinson et al. (2003) explains 4 aspects of differentiated learning: content, process, product, and learning environment. Tomlinson (2000) states that those 4 elements need to be considered in teaching differentiated instruction: (1) content relates to what students need to learn or how students will obtain lesson information; (2) process includes activities in which students are engaged to understand and master facts, keys, concepts, and skills from the subject matter; (3) product is a task to demonstrate what students know, understand, and are able to do as a result of learning; and (4) learning environment describes how the classroom operates and interacts.

Roy, Guay, and Valois (2012) define differentiated instruction as a varied and adaptive learning approach that adjusts to student ability by using systematic procedures to monitor academic progress and make decisions based on data. Roy, Guay and Valois (2012) suggest that there are 2 components in differentiated instruction, namely, instructional adaptations and academic progress monitoring. Several studies have shown 
that the use of differentiated instruction by teachers has a positive effect. Noble's (2004) research reveals that the application of differentiated instruction approaches in teaching contributes to an increase in teachers' selfefficacy in their ability to teach students of varying cognitive levels. In addition, teachers are expected to practice creativity and flexibility in applying differentiated instruction teaching approaches. Danielson (2008) reveals that differentiated instruction relates to the professionalism of teachers. Effective teachers will focus on the diversity of student learning needs and use differentiated instruction teaching approaches. Those teachers will eventually become more competent, creative, and professional. Based on the above explanation, this study examines whether training on differentiated instruction can improve teachers' sense of efficacy in inclusion schools. The hypothesis proposed in this research is that differentiated instruction training improves teachers' sense of efficacy in inclusion schools.

\section{Research Methodology}

\subsection{Subjects}

The subjects in this study include 5 teachers (male and female) working at inclusive Baciro Public School in Jogjakarta.

\subsection{Research Design}

This research is an experimental study in which the independent variable is the teachers' sense of efficacy. The experimental design used in this research is the one group pre-test post-test design. This design requires only one group to participate, and prior to the intervention, the teachers' efficacy (pre-test) is measured. Following the study, the teachers' efficacy (post-test) will be measured again (Fraenkel, Wallen and Hyun, 2012). The experimental design is as follows:

\section{$\mathrm{O} 1 \mathrm{X} \mathrm{O} 2$}

$$
\begin{aligned}
& \mathrm{O} 1=\text { pre-test } \\
& \mathrm{X}=\text { treatment } \\
& \mathrm{O} 2=\text { post-test }
\end{aligned}
$$

\subsection{Data Collection}

The data is collected using the teachers' sense of efficacy scale, developed by Woolfok and Hoy (1993).

\subsection{Data Analysis Techniques}

This research uses quantitative analysis, which aims to test the hypothesis by using the static analysis Non Parametric Test Wilcoxon. The objective is to identify the difference between teacher efficacy before being treated (pre-test) and after being treated (post-test) in the experimental group. 


\section{Results}

\subsection{Data Description}

The study originally used 9 participants, however not all of those participants were able to complete the training session, and only 5 participants completed the training. Table 1 provides descriptions of the 5 participants.

Table 1. Description of Teacher Sense of Efficacy Statistics Pre- and Post-Test Experiment Group

\begin{tabular}{lll}
\hline & Experiment & \\
\hline Subject & Pre-test & Post-test \\
\hline ES & 84 & 89 \\
T & 61 & 105 \\
R & 90 & 94 \\
S & 86 & 89 \\
ESH & 74 & 93 \\
\hline
\end{tabular}

The hypothesis in this study states that differentiated instruction training improves the sense of efficacy of inclusive school teachers at Baciro Elementary School. The hypothesis was tested by using the Non Parametric Wilcoxon Test. The results of the analysis of the Wilcoxon test are displayed in the following table.

Table 2. Statistic Descriptive

\begin{tabular}{llll}
\hline & $\mathrm{N}$ & Mean & Std. Deviation \\
\hline PRE & 5 & 79,0000 & 11,66190 \\
POST & 5 & 94,0000 & 6,55744 \\
\hline
\end{tabular}

Table 2 shows that from the pair of analyzed samples that show correlation, there are differences in the mean values before training and after training. The mean value before the training is 79,0000, with a standard deviation of 11.66190, which increased after the training was delivered to a mean value of 94,0000 , with a standard deviation of 6.55744 .

Table 3. Test Statistics

\begin{tabular}{ll}
\hline & PRE-POST \\
\hline Asymp. Sig. (2-tailed) & 0,043 \\
\hline
\end{tabular}

Table 3 illustrates that there is no difference in teachers' efficacy in the experimental group after being given differentiated instruction training when using the teacher sense of efficacy scale (TSES) scale, as the the $\mathrm{p}$ value is $0.043(\mathrm{p}<0.05)$.

\section{Discussion and Conclusion}

The purpose of this research is to understand the ability of differentiated instruction training to improve teachers' sense of efficacy in inclusion schools. The results show that there is a difference between the efficacy of teachers in the experimental group after being given differentiated instruction training using the teacher sense of efficacy scale (TSES), based on the $p$ value of 0.043 ( $p<0.05$ ). It is therefore concluded that teachers' sense of efficacy changes with differentiated instruction training. This is consistent with research by Stosovic, Nikoloc, and Popadic (2015), which implies TSES on inclusive schools. In his research, Stosovic et 
al. uses a sample of 148 elementary school teachers using a long format TSES. According to that research, TSES has a positive influence on teachers' readiness to accept innovative teaching practices, such as meeting with students in need. Further, research conducted by Moran and McMaster (2009) identified a correlation between teachers' self-efficacy and the delivery and implementation of new learning strategies to students. Conversely, teachers who are less open to implementing diverse learning strategies in the classroom have gradually declining self-efficacy with respect to teaching students with learning difficulties.

A literature review conducted by Dibapile (2012) found that teachers' beliefs help them plan effective learning strategies according to the needs of each student, improve teachers' work, and improve teacher effectiveness and productivity. Further, research conducted by Sunjin Oh (2010) concludes that teachers' self-efficacy is significantly influenced by their experience in teaching, where it is related to instructional strategies tailored to student needs, classroom management, and student involvement in the learning process.

Research conducted by Fuchs, Fuchs, and Bishop, Woolfolk, Rosoff, and Hoy (Neve, Devos and Tuytens, 2014) has shown that there is a relationship between teachers' effectiveness and classroom behavior, such as innovation in the learning process, using classroom management strategies, and using structured instruction in the classroom. In addition, teachers who have high levels of efficacy are also able to change their instructions in a structured way, including the use of DI learning.

A similar study was conducted by Gibson and Dembo (Neve et al., 2014), which suggests that teachers with high levels of efficacy are able to provide instruction to students who are experiencing difficulty or a lack of motivation by providing additional instructions according to the needs of the students. Werthheim and Leyser (Neve et al., 2014) also reveal that teachers with high personal efficacy in teaching are more likely to use differentiated teaching strategies.

Wertheim and Leyser (2016) identify a close connection between teachers' self-beliefs and the selection of differentiated teaching strategies in inclusive classes. Teacher's self-confidence in this study refers to a teacher's belief that he/she has the skills and abilities to influence student behavior and learning. The ability to influence student behavior and learning processes is illustrated by instructional activities in the classroom and organizing and directing student behavior. Based on the results of this study, it is concluded that differentiated instruction training improves teachers' sense of efficacy in inclusive schools, at Baciro Elementary School.

\section{Acknowledgements}

The authors would like to thank the Indonesia Government for its financial support of the Research Grant No. 012/DirDPPM/70/DPPM/PascaDoktor-KEMENRISTEKDIKTI/IV/2017, under the Ministry of Research, Technology and Higher Education, the Republic of Indonesia and Universitas Islam Indonesia, Jogjakarta, Indonesia.

\section{References}

Chao, C. N. G., Forlin, C., \& Ho, F. C. (2016). Improving teaching self-efficacy for teachers in inclusive classrooms in Hong Kong. International Journal of Inclusive Education, 20(11), 1142-1154.

Corno, L. Y. N. (2008). On teaching adaptively. Educational Psychologist, 43(3), 161-173.

Danielson, C. (2008). The handbook for enhancing professional practice: Using the framework for teaching in your school. ASCD.

Dibapile, W. T. S. (2012). A review of literature on teacher efficacy and classroom management. Journal of College Teaching \& Learning (Online), 9(2), 79.

Dixon, F. A., Yssel, N., McConnell, J. M., \& Hardin, T. (2014). Differentiated instruction, professional development, and teacher efficacy. Journal for the Education of the Gifted, 37(2), 111-127.

FORLIN, C. (2013). Issues of inclusive education in the 21st century. 学習開発学研究, (6), 67-81.

Fraenkel, J. R., Wallen, N. E., \& Hyun, H. H. (2012). How to Design and Evaluate Research in Education (8th edt.). New York: McGram-Hill Companies. 
Hoy, W. K., \& Woolfolk, A. E. (1993). Teachers' sense of efficacy and the organizational health of schools. The elementary school journal, 93(4), 355-372.

Mahony, C. (2016). Assessing teachers' attitudes towards inclusive education within an urban school district in Ireland.

Tschannen-Moran, M., \& McMaster, P. (2009). Sources of self-efficacy: Four professional development formats and their relationship to self-efficacy and implementation of a new teaching strategy. The Elementary School Journal, 110(2), 228-245.

De Neve, D., Devos, G., \& Tuytens, M. (2015). The importance of job resources and self-efficacy for beginning teachers' professional learning in differentiated instruction. Teaching and Teacher Education, 47, 30-41.

Oh, S. (2010). The sources that influence student teachers' sense of efficacy.

Roy, A., Guay, F., \& Valois, P. (2013). Teaching to address diverse learning needs: Development and validation of a differentiated instruction scale. International Journal of Inclusive Education, 17(11), 1186-1204.

Shaukat, S., \& Iqbal, H. M. (2012). Teacher self-efficacy as a function of student engagement, instructional strategies and classroom management. Pakistan Journal of Social and Clinical Psychology, 9(3), 82-85.

Ilić-Stošović, D., Nikolić, S., \& Popadić, M. (2015). Teachers' sense of efficiency and implications for the implementation of inclusive education1. Special education and rehabilitation, 14 (3), 345-365.

Tomlinson, C. A. (2000). Differentiation of Instruction in the Elementary Grades. ERIC Digest.

Tomlinson, C. A. (2001). How to differentiate instruction in mixed-ability classrooms. ASCD.

Tomlinson, C. A., Brighton, C., Hertberg, H., Callahan, C. M., Moon, T. R., Brimijoin, K., ... \& Reynolds, T. (2003). Differentiating instruction in response to student readiness, interest, and learning profile in academically diverse classrooms: A review of literature. Journal for the Education of the Gifted, 27(2-3), 119-145.

Wertheim, C., \& Leyser, Y. (2002). Efficacy beliefs, background variables, and differentiated instruction of Israeli prospective teachers. The Journal of Educational Research, 96(1), 54-63. 